Journal of Critical Race Inquiry

Volume 4, Number 1 (2017) pp. 25-53

\title{
The University as a Neoliberal and Colonizing Institute: A Spatial Case Study Analysis of the Invisible Fence between York University and the Jane and Finch Neighbourhood in the City of Toronto
}

\section{Ardavan Eizadirad}

Department of Curriculum, Teaching, and Learning at Ontario Institute for

Studies in Education (OISE), University of Toronto

\begin{abstract}
Jane and Finch is notoriously known in the City of Toronto as a high profile "Priority Neighbourhood" characterized by poverty, crime and violence. And yet, it is situated in close proximity to York University, a place of higher learning characterized by modernism, order, multiculturalism, and innovation. Using a spatial analysis, the first half of this essay traces the social, cultural, and historical development of Jane and Finch and York University, contrasting the rapid development and expansion of York University in relation to the slow growth and deteriorating living conditions of Jane and Finch. The second half of the essay explores the racialization of physical and social differences between York University and Jane and Finch. In particular, I explore how interlocking systems of domination produce, maintain, and (re)produce an invisible fence that constitutes York University as a civilized space and Jane and Finch as a spectacle of violence and delinquency. Overall, this article uses York University as a case study to argue that the university, as an extension of the State, participates in a neoliberal and colonizing project that constructs York University as a safe place of higher learning at the expense of social marginalization, stigmatization, and exclusion of the Jane and Finch community and Othering of its residents. By the racialization of Jane and Finch and Othering of its immigrants and visible minorities, York University exemplifies
\end{abstract}


the processes by which whiteness is protected and privileged and the university's perpetuation of poverty and violence in Jane and Finch are masked. ${ }^{1}$

Key Words: spatial analysis, York University, Jane and Finch, white privilege, racialization, Othering, colonization, and neoliberalism

\section{Introduction to Spatial Analysis: Interlocking Systems of Domination and Oppression}

Spatial analysis can serve as a medium to examine how interlocking systems of domination and oppression operate dynamically and simultaneously, co-constituting one another through each other (Razack, 2002). It is through such vantage point that the myth of "space" as naturally evolving is debunked (Lefebvre, 1991). Instead, one can view elite spaces such as the university as a spatial product that is socially, culturally, and politically constructed through a web of unequal power relations that benefit colonizers at the expense of oppressing and marginalizing the colonized. Spatial analysis as a tool functions to denaturalize and disrupt what often is accepted as "the way things have always been" through contextualization and historicizing, referred to by Razack (2002) as "unmapping." Razack (2002) points out that, "unmapping is intended to undermine the idea of white settler innocence (the notion that European settlers merely settled and developed the land) and to uncover the ideologies and practices of conquest and domination" (p. 5). More importantly, "unmapping" provides a counter-narrative that critically questions and deconstructs what is presented as objective "truth" within the dominant discourse as told from the perspective of the colonizer.

Borrowing from Razack's (2002) concept, the objective of this spatial case study analysis is to unmap, historicize, and contextualize the role of York University as an apparatus of the white settler society participating in practices of conquest and domination which (re)produce racial hierarchies and a socially stratified Canadian society. The first part of the essay traces the social, cultural, and historical development of Jane and Finch and York University, contrasting the slow and deteriorating living conditions of Jane and Finch in relation to the rapid development and expansion of York University. The second half of the essay explores the racialization of physical and social differences between York University

\footnotetext{
${ }^{1}$ A preliminary draft of this paper was presented at the OISE $15^{\text {th }}$ Annual Dean's Graduate Student Research Conference on March 7th 2015 in Toronto, Canada. Thanks to Dr. Sherene Razack for introducing me to the concept of spatial analysis and for feedback on the initial draft of this paper.
} 
and Jane and Finch. In doing so it emphasizes how interlocking systems of domination produce, maintain, and (re)produce the invisible fence and how this benefits specific social groups at the expense of marginalization to others.

Several guiding questions will lead this spatial case study analysis: What ideological and symbolic meanings are associated with the representations of the spaces? Who is privileged within these spaces? Who profits from the current representations of the spaces and simultaneously who is oppressed and disadvantaged? Who gets access to the spaces and for what purposes? Who is being silenced, not represented, or misrepresented? How are certain bodies marked as Othered and different? How are bodies occupying these spaces surveilled and policed? How is the law applied differently to the various bodies occupying and living within these spaces? How is violence enacted differently on bodies within these spaces? These questions serve as a road map to explore and make the argument that York University, as an extension of the State, participates in the neoliberal and colonizing project. This project, I argue, contributes to the establishment of York University as a safe, civilized place of higher learning at the expense of social marginalization, stigmatization and exclusion to the Jane and Finch community and Othering of its residents.

\section{Brief History of Jane and Finch}

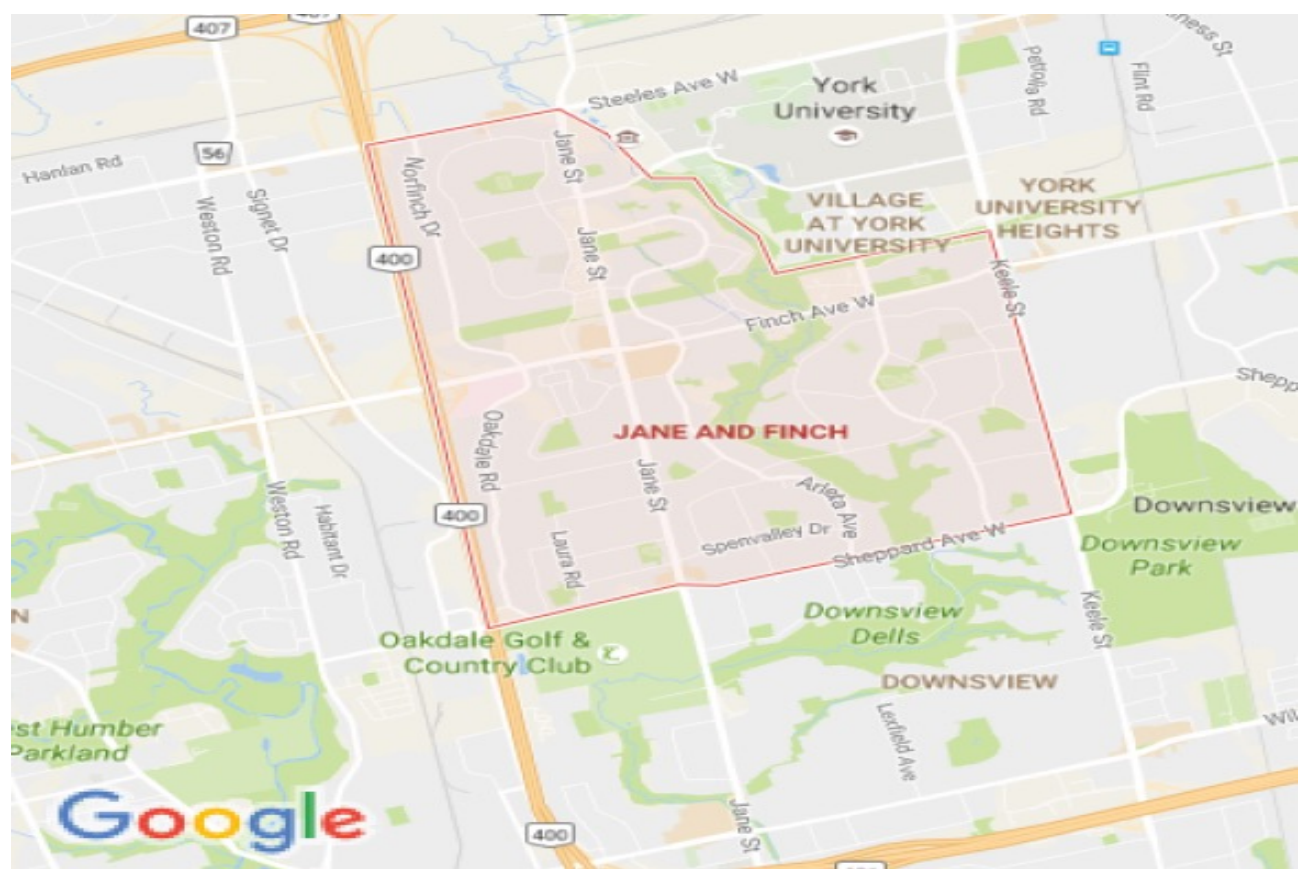

Figure 1. Map of the Jane and Finch Neighbourhood. (Google Maps, 2016) 
Jane and Finch is a neighbourhood located in the former city of North York in northwestern Toronto, Ontario, Canada. It is centred around the intersection of two arterial roads: Jane Street and Finch Avenue. The area is roughly bounded by Highway 400 to the west, Driftwood Avenue to the east, Grandravine Drive to the south, and Shoreham Drive to the north (Leon 2010; Narain, 2012). Starting in 2005, the City of Toronto identified thirteen "Priority Neighbourhoods" to receive extra attention for the purpose of neighbourhood improvement in various capacities. In March 2014, the City of Toronto expanded the program to include 31 identified neighbourhoods and re-named the program from "Priority Neighbourhoods" to "Neighbourhood Improvement Areas" (City of Toronto, 2016). According to the City of Toronto (2016) website, the 31 neighbourhoods were selected through the Toronto Strong Neighbourhoods Strategy 2020 which identified areas falling below the Neighbourhood Equity Score and hence requiring special attention. Since inception of these neighbourhood improvement initiatives, Jane and Finch has always been one of the neighbourhoods identified as requiring special attention whether as a "Priority Neighbourhood" or a "Neighbourhood Improvement Area" (City of Toronto, 2016). According to the City of Toronto "Jane-Finch: Priority Area Profile" (2008), the neighbourhood has "an approximate population of 80,150 living within an area span of 21 kilometre squared with an average population density of 3,817 persons per kilometre squared." The neighbourhood is characterized by unemployment, single parent families, and high percentage of visible minorities, which makes Jane and Finch a constant target of negative media depictions. Within dominant narratives in the media, the social problems of the neighbourhood are often blamed on its residents without much attention being given to the systematic and structural conditions, which have influenced the neighbourhood's trajectory of development leading up to its current conditions.

The major print document that is available and accessible covering the history of Jane and Finch is called From Longhouse to Highrise: Pioneering in Our Corner of North York, published in 1986 by Downsview Weston Action Community with assistance from York University’s Community Relations Department. It traces the historical roots of Jane and Finch to roughly around 1400 where the land belonged to Indigenous Peoples living in longhouses that "were up to 120 feet long and 30 feet wide" (p. 5). In describing how the settlers obtained the land the document states:

Eventually, our Indian pioneers were forced to leave their village as the land could no longer support them. The soil had slowly lost its fertility, the forests had thinned making firewood and building timber scarce and the forest wildlife disappeared. The Indians moved north and west to new areas of plenty. (p. 5) 
This simplistic description does not outline how the Indigenous Peoples were displaced and their lands stolen with violence, which was used as a tool for conquest and domination. Rather, it paints the picture that Indigenous Peoples left because "the land could no longer support them" and the European settlers arrived shortly after. These narratives mask the violence that was enacted on Indigenous Peoples and their communities. After obtaining the land, European settlers arguably exacerbated this violence by using the land primarily for farming up until the end of World War II.

The next major change to the land occurred after World War II. Throughout the 19th century, the Jane and Finch area underwent incremental growth through investments "in building of schools, churches, and the addition of a railway in 1853" (Richardson, 2008, p. 2). As World War II ended Canada, as a nation-in-the-making, seized the opportunity to build a unique identity for itself by implementing less restrictive immigration policies and accepting immigrants from non-European countries. In order to provide living spaces for newly arrived immigrants entering the country, Canada began to invest in building affordable housing in the suburbs. As a result, in 1954 the federal and provincial government expropriated 600 acres of farmland in the Jane and Finch area for the intention of developing 3,000 low-cost homes (Lovell, 2011).

Jane and Finch underwent massive development by the Ontario Housing Commission in the 1960s to keep up with rapid rates of newcomers entering Canada (Narain, 2012). Jane and Finch represented an ideal choice for many new immigrants due to low rent costs and relatively close proximity to the downtown core of the city. At the time, immigrants that were moving into the Jane and Finch area were predominantly from West Indies, Asia, Africa, South America, and the Indian subcontinent (Richardson, 2008, p. 3). High-rise apartments and townhouses were built at a rapid rate. This linear style of hollow urban planning, without much thought to the internal infrastructure of the neighbourhood, lead to the population of Jane and Finch expanding "from 1,301 in 1961 to 33,030 in 1971," which included establishment of 21 high-rise apartment buildings in the neighbourhood (Downsview Weston Action Community, 1986; Rigakos et al., 2004). Jane and Finch continued its exponential growth in the 1970s and 1980s, with the majority of its residents working class immigrants and visible minorities (Narain, 2012).

Jane and Finch continued to be a popular place of residence for immigrants and racialized minorities through the end of the $20^{\text {th }}$ century and remains so today. As this trend continued, the neighbourhood gained "a reputation for ethnic conflict, crime, and violence which continues to haunt it today" (Richardson, 2008, p. 76). In “Canada's Toughest Neighbourhood": Surveillance, Myth, and Orientalism, Richardson (2008) argues that the 
continuous negative representation of Jane and Finch produced an image of the neighbourhood as an "uncivilized" space infested with social problems (p. 77). Needing to be questioned, however, is how Jane and Finch, of all the neighbourhoods in the City of Toronto, became the city's most notorious neighbourhood associated with violence, crime, and gangs. This requires going beyond simplistic cause-and-effect explanations to considering the social, cultural, and historical conditions that shaped the development of Jane and Finch over time.

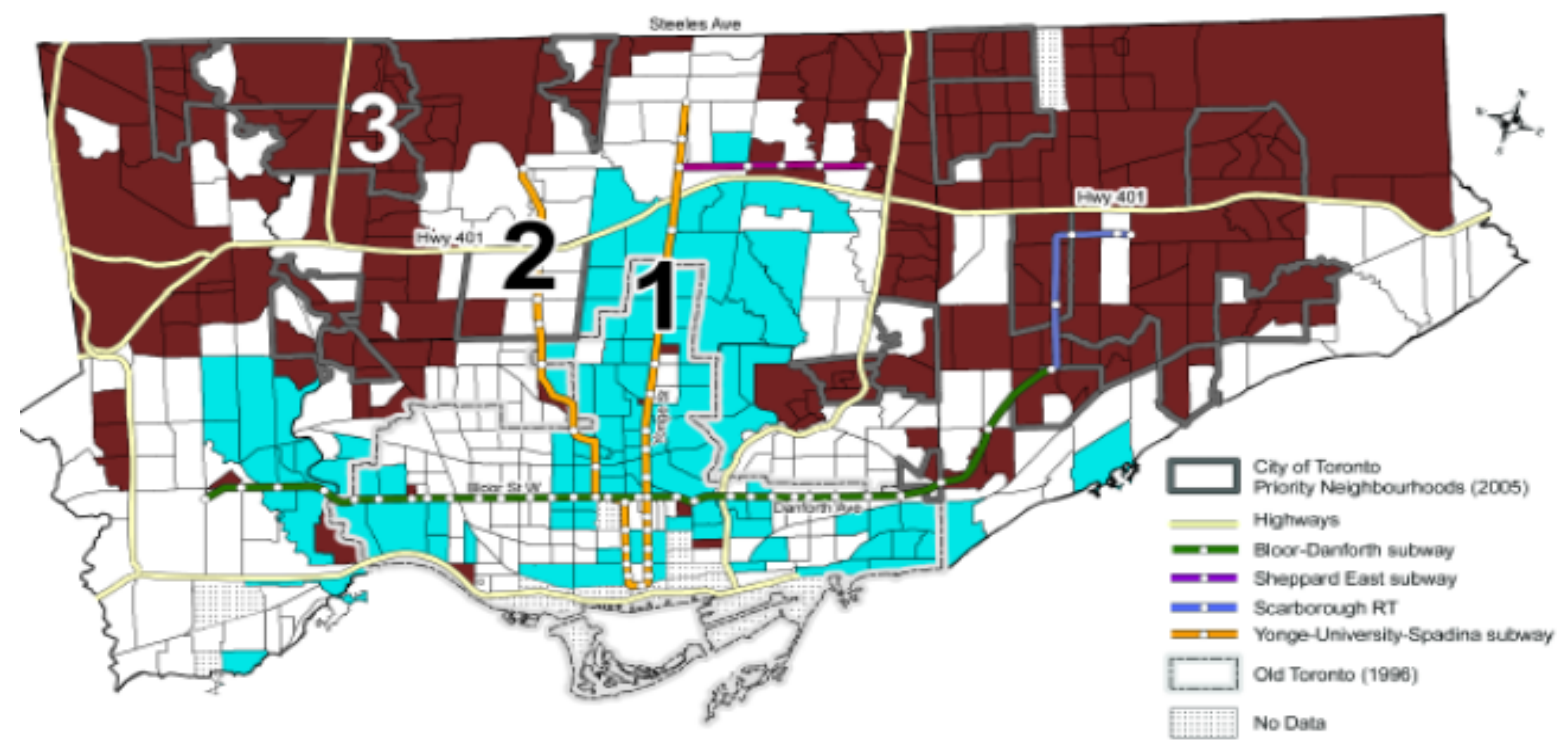

Change in the Census Tract Average Individual Income as a Percentage of the To nonto CMA Average, $1970-2005$

\begin{tabular}{lll}
\multicolumn{1}{c}{ City \#1 } & \multicolumn{1}{c}{ City \#2 } & City \#3 \\
Increase of $20 \%$ or More & Increase or Decrease & Decrease of 20\% or More \\
700 Census Trods, 20\% of City & is Less than $20 \% \%$ & 206 Census Trocts, $40 \%$ of City \\
& 208 Census Trocts, $40 \%$ of City &
\end{tabular}

Figure 2. Change in Average Individual Income, City of Toronto, Relative to the Toronto CMA 19702005. Average Individual Income from All Sources 15 Years and Over. (Hulchanski (2007)

David Hulchanski's (2007) report, “The Three Cities within Toronto," provides the means to contextualize the development of Jane and Finch in comparison to other neighbourhoods in the City of Toronto. The study provides a comprehensive examination of income polarization among Toronto's neighbourhoods from 1970 to 2005 taking into consideration neighbourhood demographics. Findings indicate emergence of three distinct cities within Toronto based on income change. "City \#1" makes up 20 percent of the city and it is generally found in the downtown core of the city, in close proximity to the city's subway lines. The neighbourhoods under City \#1 are identified as predominantly high-income areas where the average individual income increased by 20 percent or more relative to the Toronto Census Metropolitan Area (CMA) average in 1970. "City \#2" makes up 40 percent of the city 
and is characterized by middle-income neighbourhoods. Individual incomes in City \#2 remained the same, fluctuating by less than 20 percent relative to the Toronto Census Metropolitan Area (CMA) average in 1970. "City \#3" makes up the final 40 percent of the city and includes the Jane and Finch area. Individual incomes in City \#3 have undergone a decrease of 20 percent or more relative to the Toronto Census Metropolitan Area (CMA) average. There are other major differences between City \#1 and City \#3, particularly in terms of the number of immigrants and visible minorities living in the areas. 82 percent of City \#1 is white compared to 34 percent of residents in City \#3. The percentage of foreign-born individuals in City \#1 declined from 35 to 28 percent between 1971 and 2006, whereas in City \#3 the number of immigrants increased, from 31 percent of the population in 1971 to 61 percent in 2006 (Hulchanski, 2007, p. 11). These statistical trends confirm that, since the 1970s, the majority of residents of Jane and Finch have been immigrants and visible minorities. As of 2008, 70.6 percent of the Jane and Finch population are visible minorities (City of Toronto, 2008).

Hulchanski's data demonstrates drastic differences in long-term neighbourhood trends within Toronto. More importantly, these data deconstruct the fallacy that neighbourhoods simply evolve "naturally" and by chance. That is, long-term trends from Hulchanski's findings indicate that investments and resources are inequitably distributed to different neighbourhoods in the City of Toronto; neighbourhoods composed of majority white residents are privileged at the expense of systemic neglecting of neighbourhoods composed of majority working class immigrants and visible minorities. For Jane and Finch, the lack of investment in the infrastructure of the neighbourhood along with lack of accessibility to social programs, employment, and resources resulted in "the most ripe of conditions for concentrated urban poverty to develop" (Rigakos et al., 2004, p. 17). Instead of acknowledging that the urban planning of Jane and Finch was a recipe for failure, the City of Toronto-along with the media-employed social, cultural, and racial biases to instead place the blame of the social problems plaguing the neighbourhood on the residents of the area (Zaami, 2012). 


\section{Brief History of York University}
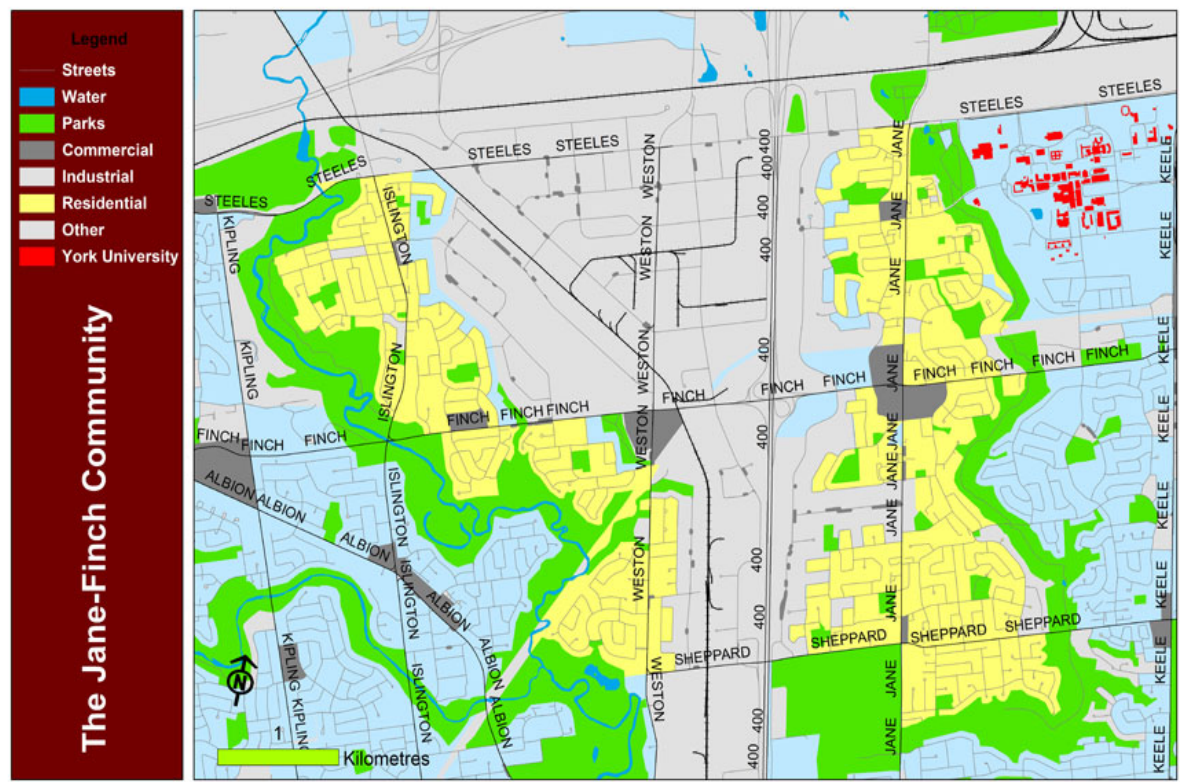

Figure 3. The Jane-Finch Community and York University. (York University, n.d.)

The construction of York University occurred during a period of rapid expansion for Canadian post-secondary institutions, coinciding with the post-World War II "baby boomer" generation coming of age (Unterman and McPhail, 2008). A large percentage of the Canadian population between the 1950s and 1970s was young and, in order to address their needs, the provincial government of Ontario invested in building a new university in Toronto to increase accessibility to post-secondary education. As a result, York was incorporated in March 1959 "with the biggest task ahead being the actual development of the University" (York University, 2012).

The province anticipated that the new university would initially struggle to establish itself due to lack of credibility or recognizable name. Therefore, one of the conditions outlined by the legislation which approved the building of York University was for the university to be affiliated with the University of Toronto in its early stages "for a period of not less than four years and not more than eight years" (Ross, 1992, p. 66). This was intended to assist York University in transitioning to establish itself with credibility and adequate scholastic standards. York University began its operation in the fall of 1960 as an affiliated college of the University of Toronto. Classes took place at the downtown University of Toronto campus. The following year classes were moved to York's Glendon College Campus located near Bayview Avenue and Lawrence Avenue East (Unterman and McPhail, 2008, p. 9). In 1961, the York Board of 
Governors began searching for an ideal location to build a new large campus in order to establish York as an independent university that would accommodate a greater number of students.

At the time of its incorporation, the York Board of Governor's had the vision of building "a large, urban, multi-Faculty campus that would eventually accommodate 7,000 to 10,000 students" (York University, 2012). The Keele Campus site, located near Jane and Finch, was selected as an ideal location because it was expected that "the movement of population in Toronto would be towards the northwest and it would be accessible to future main traffic arteries" (York University, 2012). York pursued this location and, in 1962, the Province of Ontario gave York University 474 acres of previously expropriated land near the Jane and Finch area to start the initial construction and development of the Keele Campus (Unterman and McPhail, p. 9). The planning and construction took approximately three years to be completed. In 1965, York University ended its affiliation with University of Toronto and declared independence by opening its Keele Campus. The location of the Keele Campus proved to be a good choice as enrolment of students increased at a rapid rate over the following years and the area became more accessible by cars and public transportation. What York University did not anticipate, however, was that the neighbourhood adjacent to it_-Jane and Finch - would become known as the most notorious neighbourhood in the City of Toronto with unprecedented levels of poverty, crime, and violence.

\section{The Invisible Fence between York University and Jane and Finch}

The following sections, through a spatial analysis, explore the physical and sociospatial differences that construct and (re)produce what I argue is the "invisible fence" between York University, on the one hand, and Jane and Finch, on the other. York University and Jane and Finch have had unique and significantly diverse trajectories in terms of their development, yet they occupy nearly the same physical space. Jane and Finch is a "Priority Neighbourhood" in the City of Toronto, associated with poverty, crime, and violence; York University has expanded and established itself as the "third largest university in the country with a community of 55,000 students and 7,000 faculty and staff” (York University, 2012). As the examples of the racialized differences discussed will demonstrate, the invisible fence manifests itself in a dynamic and intentional manner involving inequitable power relations between the university and the neighbourhood. The invisible fence, under neoliberal tactics in particular, operates in a manner that secures the interests of the university at the expense of 
marginalization of the Jane and Finch neighbourhood and the Othering of its residents. It is important to emphasize that the invisible fence is actively constructed through the intersectionality of various structures and their processes, thus it cannot be understood as an accident, but rather the outcome of a particular set of inequalities.

\section{Socio-Spatial Characteristics of the Invisible Fence}

Settler colonialism, in the ways in which the land is occupied and used, constructs the dichotomy between the "civilized" and "uncivilized." The notion that Indigenous Peoples did not properly use and cultivate the land, and hence had no title to it, forms the basis of the "doctrine of discovery" which provides the foundational framework for legal claims to the land (Smith, 2005, p. 56). As Wolfe points out in Settler Colonialism and the Elimination of the Native (2006), "the ideological justification for the dispossession of the land from the indigenous peoples was that settlers would use the land better" (p. 389). Within this paradigm, settler colonialism becomes synonymous with modernity, whereas Indigenous Peoples are seen as "pre-modern." The construction of this difference thus dehumanizes Toronto's First Nations as Othered "savage" subjects who are unable to cope with transitioning to an age of modernity and technology.

Furthermore, narratives explaining how the land changed ownership is predominantly told from the perspective of white settlers. In these narratives, certain fragments of history are purposefully forgotten, erased, and silenced, particularly the extensive violence enacted on Indigenous Peoples as a means of displacing them and dispossessing their land. In my arguments regarding York University, I propose that York University should be understood as an extension of the State, directly participating in reproducing white settler narratives through knowledge production. A clear example is the involvement of York University in publishing the document From Longhouse to Highrise: Pioneering in Our Corner of North York, which depicts Indigenous Peoples as "savages" who migrated from the land on which the university now stands not because they were forced - which they were-but because they simply felt that the land was not fertile enough. The production of such narratives by York University serves two purposes: a) it masks the dark history of a white settler Canadian society; and b) it masks the dark history of the university in its role as a colonizing institution. As a result, York University's space is constructed as an ahistorical space distant from the atrocities and violence of the past.

At the local level, York University marks itself as an elite "civilized" space in relation to Jane and Finch through its unique physical appearance and its symbolic representation. 
Similar to colonial discourse, which relies on binaries, there is a dualistic difference in terms of the physical appearance and architectural design of buildings in Jane and Finch, on the one hand, and York University, on the other. That is, Jane and Finch is primarily characterized by government housing which includes semi-detached houses and high-rise buildings with some having up to "427 units and reaching as high as 33 floors" (James, 2012, p. 31). Most of the buildings in Jane and Finch are now more than 40 years old and are in deteriorating conditions. In contrast, York University's architectural design and representation is aligned with a Eurocentric appearance outlined in the 1963 York University Master Plan, which imposes specific restrictions in terms of what can be built and how it can be built. For example, the height of all structures within the campus is "to be restricted to a maximum height of 125 feet" (Unterman and McPhail, 2008 p. 11). According to the "York University Cultural Heritage Assessment Report" (2008), the "designed built form was to project and maintain an urban feel through closely spaced buildings set amongst paved or planted quadrangles, after the example of old European universities and towns" (p. 10). The production of a Eurocentric appearance assists York University in constructing a unique identity associated with order and modernism, particularly when juxtaposed with the Jane and Finch neighbourhood.

While Jane and Finch has experienced minimal improvements in terms of its physical living conditions since the 1960s, York University has undergone massive growth at a rapid rate to improve its campus buildings and facilities. York University continues to expand by receiving funding and sponsorship from public and private sectors. By focusing exclusively on profits and the interests of the university, York University directly participates in creating a visual divide between what constitutes York University, on the one hand, and Jane and Finch on the other. The university utilizes its numerous funds to maintain, improve, and invest in the creation of new buildings, faculties, and facilities as a means of improving the physical representation of the university space and what it can offer. Prime examples of recent big projects include the building of a \$45 million Aviva Centre Stadium which opened in 2004 and hosts an annual prestigious tennis tournament; the building of a sport stadium which hosted track and field events as part of the 2015 Pan-American games in Toronto; and the ongoing development of a direct subway line to the York University Campus (York University, 2012). 


\section{Urban Neoliberalism and Privatization of Spaces}

Although York University has a commitment to strengthen partnerships with the surrounding community, these relations are constructed through the university's interest in profit. York University Development Corporation (YUDC), which was incorporated in 1985 by York University, is responsible to "develop and manage innovative, community-focused, and profitable real estate projects and to strengthen partnerships with the university community's many stakeholders, neighbours, and all levels of government" (York University Development Corporation, 2012). YUDC utilizes urban neoliberalism tactics to privatize property on the York Campus as a means of maximizing profit for the university, which in effect excludes residents of the Jane and Finch neighbourhood from accessing the space that is, in fact, part of their community.

Boudreau, Keil, and Young (2009) explore the implications of neoliberalism in how it influences regulation of everyday life:

Urban neoliberalism refers to the contradictory re-regulation of everyday life in the city. Built on models of technologies of power developed in the previous era, the everyday now has become a tight place where individuals (divided by class, race, gender, etc.) are suspended in a web of control and opportunity, rights and responsibilities, further massification, and controlled isolation. (p. 29)

An example of urban neoliberalism by York University occurred in 2002 when YUDC sold about 130 acres of land near the south boundary of the York campus to Tribute Communities Builder/Developer "at a per-acre-cost of $\$ 450,000$ " for the creation of 845 private houses marketed as "The Village at York" (Saunders, 2005, p. 21). Interestingly, during sale negotiations between YUDC and Tribute Communities, Joseph Sorbara, the Chair of the YUDC Board, explicitly stated that "there would not be an opportunity in this proposal to develop subsidized housing and the plan is not to develop student housing although students might end up renting space in some of the residential homes" (Saunders, 2005, p. 21). As well, Tribute Communities negotiated the "requirement for an opportunity to acquire further land to the north" of the campus in the near future (Saunders, 2005, p. 18). Although York University consented to the use of its name by the developer of the property, it has no ownership and legal jurisdiction within the privately-owned residential community composed of condominium townhouses, semi-detached, and detached homes built in sync with the modernistic architectural design of York University. York University further agreed that as one of the conditions of the land purchase the home owners would get free access to the university's facilities including the fitness centre, indoor pool, gym, squash courts, and the 
outdoor tennis courts (Saunders, p. 3). The close proximity to public transportation and accessibility to numerous highways significantly added to the property values of the houses.

The Village at York private housing community is located on the York University Campus and serves as a prime example of neoliberal urban planning whereby "neoliberalism endorses privatization of formerly public space in order to enhance capital accumulation and establish spaces that can easily be governed" (Narain, 2012, p. 60). The houses within The Village at York are marketed as upscale and are expensive relative to properties in the Jane and Finch neighbourhood - ranging from $\$ 279,990$ to $\$ 458,990$ (Saunders, p. 3). With the exponential growth in Toronto housing market prices in the last few years, the value of homes in The Village at York has substantially increased and, as of 2016, houses were for sale in the range of $\$ 700,000$ to $\$ 900,000$. Needless to say, this is unaffordable for the residents of Jane and Finch, who earn an average after-tax income of \$49,155 (City of Toronto, 2008). As a result, housing in this context acts as a medium for gentrification because only those who have the necessary purchasing power are given access to the space and, importantly, the perks that come with ownership of a house in The Village at York. In contrast, many residents of Jane and Finch are renting or residing in subsidized high-rise apartments and are socially excluded from The Village at York. Goldberg (1993) refers to this process as "spatial circumscription" where, through privatization, "the racial poor are rendered peripheral in terms of urban location and marginalized in terms of power" (p. 188).

\section{Intentional Racialization of Space}

Through privatization everyday life is "re-regulated" (Boudreau et al., 2009) by imposing restrictions on who can own property and what can be done within that property. The interlocking dynamics of race and class in today's society lead to the confinement of living space for the poor and the working class in urban communities. That is, spaces such as The Village at York become owned by and accessible for the affluent-who are predominantly white - while simultaneously residents of Jane and Finch, most of whom are visible minorities and have resided in the area for decades, are excluded from entering the space because of the private status of the property. This contributes, within the dominant imagination, to the establishment of a sense of order and autonomy within the private space distant from the "chaos" of the public and "uncivilized" space of the Jane and Finch neighbourhood.

Goldberg and Hristova (2007) argue that the "intentionality" of racial segregation deems itself invisible through neoliberalism. Goldberg and Hristova go on to expand that 
privatization of property makes inequitable distribution of resources appear as "natural" phenomenon. By spatially tracing the history of New Orleans pre- and post-Hurricane Katrina, Goldberg and Hristova make race the forefront of their argument in dissecting neoliberalism and its subtle implications. Central to their analysis is tracking accessibility to housing and its pivotal role in the reconfiguration of the New Orleans population from a city that was mainly Black to, post-Katrina, becoming increasingly white. Goldberg and Hristova demonstrate how over time and through neoliberal tactics of privatization, boundaries were shifted and redrawn such that privilege was bestowed on the wealthy and white, while living space for the Black and poor was further constricted, limited, and confined.

An initial process in gentrification and homogenizing of certain spaces is the representation of the space as desirable in order to attract the wealthy, who because of the interlocking dynamics of race and class, tend to also be white. York University directly participated in this process through the re-branding project which re-named Jane and Finch to University Heights. This was proposed in 2007 by Councillor Anthony Perruza of Ward 8, which includes the Jane and Finch community. In The Re-Branding Project: The Genealogy of Creating a Neoliberal Jane and Finch, Narain (2012) points out that the re-branding process is a top-down initiative guided with neoliberal tactics that works "to marginalize and gentrify communities by promoting the privatization of public spaces" without consultation with the residents of the neighbourhood (p. 55). Narain goes on to contrast the positionality and power of politicians, government agencies, and economic stakeholders with that of local residents of the community, asking, "re-branding for whose benefits?" Narain demonstrates that although the re-branding may be refreshing in that it is a break from the fear and danger-focused rhetoric usually aimed at Jane and Finch, the re-branding is ultimately detrimental to Jane and Finch residents. The gentrification process this re-branding engenders, through raising property values by associating the neighbourhood with York University and public transportation infrastructure, will make it more difficult for many residents of Jane and Finch to afford living in the area. This results in the exclusion of the poor. As Blomley (2003) points out, "Indeed, the poor are, if anything, imagined as a threat to property, not only because of their assumed complicity in property crime, but also because, by their presence, they destabilize property values, both economically and culturally" (p. 125).

What is more problematic about the re-branding of the Jane and Finch neighbourhood to University Heights is that it does not constructively attempt to resolve the systemic social issues plaguing the Jane and Finch neighbourhood. As a means of voicing their concerns in protest of the name change, many key social organizations in the neighbourhood, such as the Jane and Finch Action against Poverty, did not support the name change. These social 
organizations argued that although York University is in proximal location to the neighbourhood, it has not played a pivotal role in serving the interests of the community (Narain, p. 73). Yet without consultation with the Jane and Finch community, York University supported the re-branding project and aligned it with its 50th birthday celebrations. Ninety banners were made and placed on poles in the Jane and Finch neighbourhood costing $\$ 50,000$ dollars paid in full by York University (Kim, 2008). These banners refer to the neighbourhood as University Heights in an attempt to re-construct a new image of the neighbourhood associated with modernity, order, and progress.

I argue that the re-branding project is part of a larger colonial and neoliberal project by the State that, in this case, is supported by York University. As such, I argue that York University functions to dislocate and confine the poor as a means of re-building the neighbourhood with a new set of wealthy residents. Systemic racism and colonialism are associated with neoliberal values and qualities, although in the past systemic racism and colonialism existed irrespective of neoliberalism. However, given our current neoliberal context, systemic racism and new forms of colonialism are part of the larger neoliberal agenda. Under the guise of neoliberalism and its excessive market-driven ideologies and practices, human needs and collective needs of communities are inferiorized, oppression perpetuated, and suffering tolerated for profit. Yet, the hurtful and destructive nature of these dominant market-driven ideologies and practices are swept under the rug, often silenced and dismissed within dominant discourses. Responsibility is often exclusively judged through an individualistic lens emphasizing a person's decisions and choices without an examination of the exploitive and inequitable institutional practices that create the social conditions that present limited choice(s) to individuals and their current living conditions, such as inaccessibility to affordable housing.

There is a dialectical relationship between physical space, social space, and the identity of bodies moving through the spaces (Lefebvre, 1991; Razack, 2002). Physical space in its formation and texture not only determines who has access to the space, but it contributes to co-constituting what activities takes place in that space. As Lefebvre (1991) points out, "space thus produced also serves as a tool of thought and of action; that in addition to being a means of production it is also a means of control, and hence of domination, of power" (p. 26). Therefore, it is significant to contextualize spaces as embedded within a web of inequitable power relations that have influential power in inscribing an identity on the space itself and the bodies occupying and moving through the space.

In the case of York University and Jane and Finch, Jane and Finch often has an identity imposed upon it by external parties, reflecting its limited power in the identity-making 
process. In contrast, York University, as an institution, has the power to actively participate and engage in identity-making practices by being in control of how the university space is governed, who gets to be associated with the university as an executive member, staff, or student, and what kinds of knowledge is (re)produced and disseminated through its faculties and staff. These differences in power relations result in race being positioned and interpreted differently in relation to space. Mohanram (1999) points out, "racial difference is also spatial difference, the inequitable power relationships between various spaces and places are rearticulated as the inequitable power relations between races" (p. 3). It is estimated that the residents of Jane and Finch are "from over 72 countries and speak about 120 different languages" (James, 2012, p. 34). Yet despite this diversity, media coverage simplifies residents and disproportionately features Black residents in negative stereotypical portrayals of Jane and Finch. This process homogenizes both what Jane and Finch represents, as well as what it means to be Black. In contrast, when Blackness is associated with York University it is positioned in relation to and celebrated within discourses of "multiculturalism." Unfortunately, when "multiculturalism" is celebrated on the York University campus, the ways in which the university's decision-making is dominated by white bodies who direct the funds and resources in serving the vested interests of a white settler Canadian society gets silenced and forgotten.

York University constructs an identity for itself by associating the university space with higher class and privilege in comparison to Jane and Finch. Bodies associated with York University, primarily faculty members and students, move through the invisible fence situated between York University and Jane and Finch by conducting research in the Jane and Finch community and profiting from it through knowledge production and dissemination. This process resembles what Razack (2002) calls "the racial journey into personhood" where white bodies "move from respectable space to degenerate space and back again" in an adventure that confirms they are in control and that they can survive a dangerous encounter with the racial Other (p. 127). In contrast, racialized bodies who are residents of the Jane and Finch community often do not get access to the university space, its facilities, and the knowledge produced and disseminated. The invisible fence is thus unidirectional, with only those from York University able to move through it at their convenience. These differences in terms of social mobility, in and through spaces, demonstrates how racialized bodies are marked as inferior and socially excluded from elite spaces of the university campus. Mohanram (1999) contrasts the mobility of white and Black bodies by stating, "Whiteness has the ability to move and the ability to move results in the unmarking of the body. In contrast, Blackness is signified through a marking and is always static and immobilizing” (p. 4). 


\section{Power, Poverty, and University-Community Partnerships}

According to Murji and Solomos (2005),

as a concept racialization is useful for describing the processes by which racial meanings are attached to particular issues, often treated as social problems, and with the manner in which race appears to be a, or the, key factor in the way they are defined and understood. (p. 3)

Within this framework, poverty is racialized and situated as born from Othered bodies from Jane and Finch. In contrast, York University positions itself as a sterile space free from poverty. Yet, poverty is not an independent variable but rather a result of unequal distribution of wealth and resources. The majority of Jane and Finch residents who live in high-rise buildings in the neighbourhood rent as part of Toronto Community Housing initiatives, which seek to provide affordable housing to a wide range of individuals, primarily "seniors, families, singles, refugees, recent immigrants to Canada and people with special needs" (Toronto Community Housing, 2012). The high number of high-rise buildings in the Jane and Finch community has implications in terms of the over-crowding it creates and the power struggle to access the limited resources available within the neighbourhood. In "Poverty by Postal Code 2: Vertical Poverty" (2011), United Way of Greater Toronto "tracks the continued growth of the spatial concentration of poverty in the City of Toronto" indicating that high-rise housing plays a role in this trend (p. ii). This is done through a longitudinal examination of the City of Toronto Census Data over a 25-year period from 1981 to 2006. One of the key findings of the report is that "poverty is becoming increasingly concentrated in high-rise buildings" (p. iv). The report further identifies the construction of new private sector housing targeted exclusively for more affluent families, similar to the private housing created as at The Village at York, as a significant factor in the growing concentration of low-income tenants in high-rise buildings. As a result, many families end up living in high-rise buildings in poor conditions because they have no other choice; that is the only option they have to access affordable housing.

Dominant discourses continuously (re)produce specific forms of knowledge that oversimplify the causation of poverty and associate it with deficiency models which pathologize specific races, ethnicities, and cultures as the root causes of social problems (Portelli and Sharma, 2014). I propose that this oversimplification of the causes of poverty is done 
intentionally as part of a larger neoliberal agenda that blames victims for their circumstances. In the process the systematic, structural, and institutional forms of oppression and their interlocking nature that functions to ensure racialized bodies remain in poverty - for the benefit of colonizers - are left unexamined. The Colour of Justice Network (2007) points out that "racialized communities experience ongoing, disproportionate levels of poverty." This is supported by the fact that "between 1980 and 2000, while the poverty rate for the nonracialized European heritage population in Toronto decreased by 28 percent, the poverty among racialized families rose by 361 percent" (The Colour of Justice Network, 2007). This indicates that resources are distributed inequitably; privileging white bodies at the expense of social exclusion and the marginalization of racialized Others.

The elimination of poverty does not serve the interests of a white settler society because poverty provides the social conditions that make it possible to exploit racialized Others for labour (United Nations, 1997). For colonizers, the question is not how to eliminate poverty but rather how to limit poverty so that it is confined within certain spaces predominantly occupied by racialized bodies as a means of exploiting them for their labour (Goldberg, 1993). Poverty functions as a required component for the smooth functioning of elite spaces such as York University, where the economically powerful can depend on those living in poverty to accept minimum wage jobs often without any benefits. For York University, the close proximity of the Jane and Finch neighbourhood provides them with access to a large pool of racialized immigrant bodies who are highly educated but willing to work in minimally paid jobs due to lack of accessibility to meaningful employment (City of Toronto, 2008). With poor wages, opportunities for upward social mobility remain unlikely, and the cycle of poverty continues to perpetuate itself through systematic and structural barriers created for racialized bodies by institutional policies and practices (Block and Galabuzi, 2011). Many immigrants are well-educated and have educational degrees from their country of origin, but upon arrival to Canada their degree is not recognized or under-valued by the Canadian government, making it even more challenging to access opportunities beyond minimum wage employment (Block and Galabuzi, 2011, p. 4). National figures for Canada show that in the year 2000, immigrant men earned 63.1 cents for every dollar earned by a native-born Canadian with the same educational level (Boudreau et al., p.91). This is a reflection of how racialized bodies are exploited for the benefit of a white settler Canadian society and its institutions.

York University constructs its image as an innocent and pure space, free of external challenges by emphasizing its role in having "experts" who assist the Jane and Finch community in finding solutions to social problems of the neighbourhood through university- 
community partnerships. York University has created various "partnerships" with the Jane and Finch community as a means of trying to make education more accessible for students living in the neighbourhood. One of the well-known partnerships York University has with the Jane and Finch community is the Westview Partnership, which originated in 1992. This partnership is currently associated with 23 schools in the Jane and Finch community and "seeks to enrich the schooling experience through programs designed to meet the needs, interests and expectations of students, teachers, parents, administrators and teacher candidates" (York University, 2007; James, 2012, p. 72). Students are often mentored within various programs offered as part of the Westview Partnership, and upon completion of the program are provided with financial assistance or a university credit to facilitate their transition to start a post-secondary education at York University. A more recent partnership established with the community is a project called "Assets Coming Together for Youth: Linking Research, Policy, and Action for Positive Youth Development” which was approved to receive one million dollars over five years between 2009 to 2014 from the Social Sciences and Humanities Research Council of Canada. The overall objective of the project was "to develop a comprehensive youth strategy that will outline how marginalized urban communities like Jane and Finch can make use of their community assets to support positive youth development” (York University, 2009).

Although these "partnerships" with the community seem altruistic at first glance, in reality these initiatives are more about the university and the maintenance of a certain identity rather than the interests and the collective needs of the Jane and Finch community. That is not to say that these partnerships have no impact at all for some members from the Jane and Finch community. They do assist in making education more accessible, at least financially, for the selective few students who get to participate as part of the program. What remains problematic is that such initiatives do little to address the systemic root causes of inaccessibly to education, and greater numbers of youth continue to get caught in the cycle of poverty and violence plaguing the neighbourhood (York University, 2008). The systematic and structural barriers that make it unlikely for youth from the Jane and Finch community to pursue postsecondary education thus remain unaltered, particularly once these partnerships cease to exist. Simply put, these initiatives invest in individuals and not systems. Ultimately, these partnerships function within a non-egalitarian power relation, where the university and their "expert researchers" profit from doing research in the neighbourhood, while the community and its residents are reduced to data associated with social problems to be theorized and interpreted extensively. This process perpetuates a dualistic racialized division with regards to social differences, one that associates York University as an innocent space invincible from 
social problems and Jane and Finch as a space inherently contaminated and infested with social problems associated with immigrants and racialized bodies (Portelli and Sharma 2014; Razack, 2002).

\section{The Colonial Encounter: Justifying Violence, Surveillance, and Policing of Spaces}

York University further carves a unique identity for itself by emphasizing how different and distant it is, despite its relative closeness, to the Jane and Finch neighbourhood. That is, a binary is constructed by marketing the university as a "civilized" space associated, with whiteness and multiculturalism. In contrast, Jane and Finch is portrayed as an "uncivilized" space through the process by which it is racialized, thereby becoming negatively labelled based on a racial identity. As Frantz Fanon (1963) states in The Wretched of the Earth, "the colonial world is a compartmentalized world," and "what divides this world is first and foremost what species, what race one belongs to" (p. 3-5). The marking of Othered bodies, such as immigrants and visible minorities, becomes part of a colonial cycle which perpetuates unequal power relations by depicting two different "species" occupying York University, on the one hand, and Jane and Finch, on the other. With 70.6 percent of its 80,150 residents immigrants and visible minorities (City of Toronto, 2008), the racialized Others of the Jane and Finch neighbourhood are perceived as a threat, as troublesome, and as inherently violent.

In the case of York University and Jane and Finch, violence and delinquency are essential components in creating a dualistic division between the two spaces. York University constructs its campus as a "safe space" for higher learning. When "occasional" incidents of violence take place, such as theft or sexual assaults on campus, the Jane and Finch neighbourhood is often implicated as having cross-contaminated the space of the university. In a March 2012 issue of The Excalibur, York University's community newspaper, Editor-inChief Michael Sholars directly stated, "I don't care what statistics are brought up to argue that the York campus is just as safe as any other city; the problems are coming from the area immediately surrounding our campus, one of the most infamous high-crime areas in the country" (Criger, 2012). Positioning Jane and Finch as the primary source of violence and delinquency makes it unthinkable that the perpetrators of crime committed on campus could be members of the York University. Instead, Jane and Finch is a scapegoat for the violence and crime on campus, which further stigmatizes and marginalizes the neighbourhood. Furthermore, any issues with York University and its safety policies and practices are masked, and the discussion becomes only about the issues with the Jane and Finch neighbourhood. 
One mechanism that contributes to establishing and maintaining a social divide between York University and Jane and Finch is the difference in the policing of each space. This perpetuates the binary of two distinct worlds separated and occupied by two different species (Fanon, 1963). York University primarily relies on close circuit television cameras and 24 hour, 365 days-a-year security officers to maintain safety on its campus (York University, 2012). Conversely, Jane and Finch is heavily surveilled and monitored by Toronto Police Services. It is significant to point out that while York University has the agency to choose how it will implement and maintain safety on its campus, residents of Jane and Finch are surveilled and monitored as the Toronto Police Services see fit. The local 31 Police Division receives additional police officers to patrol the Jane and Finch neighbourhood as part of the Toronto Anti-Violence Intervention Strategy (TAVIS), which focuses on reducing guns and gang violence in "Priority Neighbourhoods." In the City of Toronto in 2005, 78 homicides occurred - the majority of them in the summer months - and TAVIS was launched the following year as a response to this sharp increase in gun-related crimes. The media labelled 2005 "summer of the gun" and "year of the gun" because 52 of the 78 homicides involved guns. This included the high profile death of 15-year-old white bystander Jane Creba on a busy downtown street on Boxing Day outside of the Eaton Centre shopping mall, which dispelled the comfort that the violence could be contained within racialized spaces (James, 2012). As a result, government funding was approved to launch TAVIS, through which additional police officers are "assigned to neighbourhoods experiencing a heightened level of violence using crime trend analysis, occurrence of mapping, and community consultation" (Toronto Police Services, 2012).

The TAVIS initiative contributes to over-policing of Jane and Finch, which in turn leads to ongoing racial profiling and marginalization of the neighbourhood as a "hot spot" for crime and violence (Narain, p. 81). According to the Toronto Police Services, "the success of TAVIS is not based on the number of arrests made but on the reduction of crime, enhancement of public trust and confidence, and the building of relationships" (Toronto Police Services, 2012). Yet, TAVIS has profoundly failed in enhancing "public trust, confidence, and building of relationships" with Jane and Finch community members, largely due to the racial profiling of community members central to TAVIS' crime reduction strategy (Narain, 2012). Racialized bodies are often subjected to police raids, random searches and relentless questioning for appearing "suspicious." This process has damaged the image of the police and their relationship with the members of the community to the point where many residents of the Jane and Finch neighbourhood refuse to cooperate with the police. 
Although York University is within the boundaries of the local 31 Police Division, heavy police presence is never visible on the university campus. Under pressure to step up its security measures after a series of sexual assaults reported on its campus dating back to 2007, York University President Mahmoud Shoukri refused to resort to the same techniques that govern and police Jane and Finch, particularly referring to extensive presence of police officers. Instead, York maintains its social divide by investing in alternative surveillance mechanisms to reassure and comfort faculty and students of safety on campus. In an open forum discussion on safety, held in November 2012 on the Keele Campus, Mahmoud Shoukri emphasized that in 2011-2012 alone York University invested \$10.2 million on safety initiatives. Shoukri went on to outline the latest developments, including hiring 10 additional security officers; all personnel retrained and certified with enhanced roles and responsibilities enabling them to make a citizen's arrest; implementation of a new alert system where security concerns are emailed to students, staff, and faculty and posted to social media websites such as Facebook and Twitter; addition of 17 new exterior emergency phones; instalment of 70 LCD screens across the campus as a means of making information more accessible; enhancing lighting on campus; and increasing campus shuttle services (York University, 2012). The implementation of increased police presence on campus was not included. This approach facilitates York University in maintaining its image as a "civilized" space distant from the violence and crime associated with the Jane and Finch neighbourhood that does, in contrast, require extensive police surveillance.

Within "lawless zones" (Wacquant, 2008) such as Jane and Finch, the use of violence by the police on Othered bodies is justified in the name of safety for the public. This is part of what can be understood as a colonial encounter that serves as a teaching moment, through which racial power is articulated by displaying and reaffirming who counts as a citizen, and who does not. This is exemplified by the death of 18-year-old Junior Alexander Manon who became a victim of police brutality on May $5^{\text {th }}, 2010$. Manon was driving west on Steeles Avenue with a friend, both of them visible minorities, and came to a stop behind a red light at Keele Street, near York University. Two police cruisers approached Manon's car, one on each side, and indicated for him to pull over. The two white officers, Constable Michael Adams and Stuart Blowers, had never worked together but had both picked up a TAVIS overtime shift (Winsa, 2012). The officers requested identification from Manon and his friend. The officers checked their profiles within the police database, and indicated to Manon that he was going to be arrested for driving with a suspended licence, which breached his bail conditions. When the police tried to arrest Manon, he began running and one of the officers began pursuing him. Constable Adams was able to catch up to Manon and tackle him. A violent struggle took 
place, with the officer punching Manon several times in the right side of the head and chest. Two civilian witnesses have stated that at least some of the blows by the police officer involved striking Manon with a walkie-talkie. Meanwhile, nine other officers arrived to assist in restraining and handcuffing Manon (Toronto Police Services, 2012), and one or more of the officers placed their weight on Manon's upper body to restrain him while another officer handcuffed him. Upon recognizing that Manon was unconscious and unresponsive as a result being held too long under this excessive weight an ambulance was called, but it was too late. Manon was pronounced dead at the scene.

The community of Jane and Finch, outraged by Manon's death, responded a few days later by planning a protest march outside the local 31 Police Division as a means of demanding justice. More than 100 people gathered with signs and flowers chanting "Justice for Junior" (Cherry, 2010). As Razack (2010) points out, "law largely forgives the perpetrators of colonial violence." Razack (2010) goes on to say, "It often does so either by viewing the instances of violence as exceptional and/or considering that the victims brought the violence on themselves - it is they who are dysfunctional, sick, prostituting themselves, posing a security threat, and so on" (92). In the case of Junior Alexander Manon, media reports indicated that he had died of a heart attack when in fact Manon was a healthy young man with no history of medical problems. Postmortem ruled Manon's death as "restraint asphyxia following a struggle and exertion” (Winsa, 2012). The Special Investigation Unit (SIU) of the Toronto Police Services cleared the officers of criminal negligence insisting that the force used on Manon was justifiable given that he was resisting arrest. The director of SIU Ian Scott stated, "Given the level of resistance from Mr. Manon and the medical finding that his cause of death was unrelated to neck injury, I am of the view that the force used to arrest him was not excessive in these circumstances" (Toronto Police Services, 2012). An inquest into Manon's death was conducted in 2011 and the jury found that the actions of the officers contributed to Manon's death, but the officers were cleared of any criminal charges because the death was ruled an accident. In essence, this legal process served to reiterate that the legal system is an ally of the colonizer and, as an institution, will protect and privilege whiteness at the expense of Black lives.

The violence enacted on Manon's body was part of a deadly encounter between the colonizer and the colonized. What could have prompted nine police officers to restrain and beat an unarmed 18-year-old to death? As Razack (2002) points out, "bodies in degenerate spaces lose their entitlement to personhood through a complex process in which the violence that is enacted is naturalized" (p. 155). In the case of Manon, he was Othered by the fact that he was Black and a resident of Jane and Finch. Simultaneously, York University quickly 
distanced itself from the incident by proclaiming that Manon was not a student at the university, even though his death occurred on the campus property. As a result, Manon was portrayed as inherently violent, emphasized by the fact that he was "known to the police" and thus the deadly force and violence enacted on his body, justified. The encounter between Manon and the Toronto Police Services reaffirmed that racialized Black bodies are noncitizens who do not get the full rights of citizenship and benefits of the law. By finding the police officers not criminally responsible, the law protected white privilege and reaffirmed the notion that "whether the bodies of the racialized Other were to be killed or colonized, slaughtered or saved, expunged or exploited, they have to be prevented at all costs from polluting the body politic or sullying civil(ized) society" (Goldberg, 1993, p. 187). Through differences in surveillance and policing tactics, Jane and Finch is depicted as a spectacle of violence, while York University is constructed as a safe, and even wholesome, space. By dismissing Manon's death as accidental, without holding anyone accountable, the State, the law, and York University, all operating as part of a colonizing system, collectively reminds us that Black lives do not matter.

\section{Conclusion}

York University, when conceived of as an extension of the State, participates in the neoliberal and colonizing project by constructing an identity for itself associated with order, modernism and progress at the expense of marginalizing and stigmatizing Jane and Finch, and Othering its residents. As a result, an invisible fence is constructed between what constitutes York University, on the one hand, and Jane and Finch, on the other. This invisible fence is maintained and (re)produced intentionally through the racialization of social and physical characteristics of Jane and Finch. Physical differences include the appearance and architectural designs of the buildings; Jane and Finch is primarily characterized by government housing such as semi-detached houses and high-rise buildings, most of which are in deteriorating condition. In contrast, York University's architectural design and representation are aligned with a Euro-centric appearance that strictly defines what can be built on its campus and how it can be built. Social differences between Jane and Finch and York University are constructed and maintained through the implementation of neoliberal policies and tactics that promote privatization and gentrification, such as is the case with The Village at York, at the cost of excluding long-time residents of Jane and Finch. The racialization of social differences are also made visible by how bodies are surveilled and policed within the spaces. Jane and Finch is 
predominantly monitored through the heavy presence of police officers and special police units such as Toronto Anti-Violence Intervention Strategy (TAVIS), whereas York University is privileged to instead invest in alternative safety measures such as closed circuit television cameras and 24 hour, 365 days-a-year security officers to ensure safety on its campus. As a result of these physical and social differences, a dominant racialized narrative emerges as told from the perspective of colonizers and supported by neoliberal and colonizing institutional practices of York University, that depicts and constructs two distinct worlds separated and occupied by two different species (Fanon, 1963). The clean and spacious environment of York University represents and symbolizes a safe place of higher learning associated with modernism, order, and multiculturalism. Opposing this, the deteriorating and over-crowded conditions of Jane and Finch constitute it as a lawless zone (Wacquant, 2008) infested with crime, gangs, poverty, and violence caused by visible minorities and immigrants. By positioning Jane and Finch as a spectacle of violence and delinquency, York University masks its own contribution to the perpetuation of poverty and violence in Jane and Finch and its insufficient efforts to break this cycle. York University operates as an apparatus of white settler society and, through its policies, practices and operations continuously racializes Jane and Finch through the construction of the invisible fence. In the process, York University contributes to (re)producing a racial hierarchy and a socially stratified society where whiteness retains a currency of privilege at the expense of marginalizing and oppressing visible minorities and immigrants, such as the residents of the Jane and Finch community.

\section{References}

Block, S., \& Galabuzi, G. (2011). Canada’s colour coded labour market: The gap for racialized workers. Wellesley Institute and Canadian Centre for Policy Alternatives. Retrieved from http://www.wellesleyinstitute.com/wpcontent/uploads/2011/03/Colour_Coded_Labour_MarketFINAL.pdf

Blomley, N. (2003). Law, property, and the geography of violence: The frontier, the survey, and the grid. Annals of the Association of American Geographers, 93(1), 121-141.

Boudreau, J., Keil, R., \& Young, D. (2009). Changing Toronto: Governing urban neoliberalism. Toronto, ON: University of Toronto Press.

Cherry, T. (2010), May 9. Mother's day march for dead teen. Toronto Sun. Retrieved from http://www.torontosun.com 
City of Toronto. (2008). Jane-Finch: Priority area profile. Prepared by the Social Policy Analysis \& Research Section in the Social Development, Finance, and Administration Division Source: Census 2006. Retrieved from http://www1.toronto.ca/city of toronto/social_development_finance administration/f iles/pdf/area janefinch full.pdf

City of Toronto. (2016). NIA Profiles. Retrieved from http://www1.toronto.ca/wps/portal/contentonly?vgnextoid=e0bc186e20ee0410 VgnVC M10000071d60f89RCRD

Colour of Justice Network. (2007). Colour of poverty. Retrieved from http://www.learningandviolence.net/lrnteach/material/PovertyFactSheets-aug07.pdf Criger, E. (2012, September 19). Jane-Finch residents protest York U newspaper. CityNews. Retrieved from http://www.citynews.ca

Downsview Weston Action Community. (1986). From longhouse to highrise: Pioneering in our corner of North York. North York, ON: Downsview Weston Action Community.

Fanon, F. (1963). The wretched of the earth. Paris, France: Presence Africaine.

Goldberg, T.D. (1993). 'Polluting the body politic': Race and urban location. In Racist culture: Philosophy and the politics of meaning. Cambridge, United Kingdom: Blackwell.

Goldberg, T.D., \& Hristova, S. (2007). Blue velvet: Re-dressing New Orleans in Katrina's wake. Vectors, 3(1). Retrieved from http://vectors.usc.edu/projects/index.php?project $=82$

Hulchanski, J.D. (2007). The three cities within Toronto: Income polarization among Toronto's neighbourhoods 1970-2005. Retrieved from http://www.urbancentre.utoronto.ca/pdfs/curp/tnrn/Three-Cities-Within-Toronto-2010Final.pdf

James, C. (2012). Life at the intersection: Community, class and schooling. Canada: Fernwood Publishing.

Kim, C. (2008, October 22). Rebranding a community. Retrieved from http://www.insidetoronto.com/news-story/29508-rebranding-a-community/

Lefebvre, H. (1991). The production of space. Malden, MA: Blackwell.

Leon, D. (2010). Community resource and need assessment version 2009 Jane and Finch. Toronto Centre for Community Learning \& Development. Retrieved from http://test.tccld.org/wp-content/uploads/2012/11/JaneFinch_2009-10_CRNA.pdf

Lovell, A. (2011). An overview of development in Jane-Finch: 1950s to present (PPT). Assets Coming Together for Youth. Retrieved from 
http://www.yorku.ca/act/CBR/AnOverviewofDevelopmentJaneFinch_AlexanderLovell . $\mathrm{pdf}$

Mohanram, R. (1999). Black body: Women, colonialism, and space. Minneapolis, MN: University of Minnesota Press.

Murji, K., \& Solomos, J. (2005). Racialization in theory and practice. In Murji, K. \& Solomos, J. (Eds.), Racialization: Studies In theory and practice. New York, NY: Oxford University Press.

Narain, S. (2012). The re-branding project: The genealogy of creating a neoliberal Jane and Finch. Journal of Critical Race Inquiry, 2(1), 54-94.

Portelli, J., \& Sharma, M. (2014). Uprooting and settling in: The invisible strength of deficit thinking. LEARNing Landscapes, 8(1), 251-267.

Razack, S. (2002). When place becomes race. In Razack S. (Ed.), Race, space and the law: Unmapping a white settler cociety, Toronto: Between the Lines.

Razack, S. (2002). Gendered racial violence and spatialized justice: The murder of Pamela George. In Razack S. (Eds.): Race, space and the law: Unmapping a white settler society. Toronto, ON: Between the Lines.

Razack, S. (2010). A hole in the wall; a rose at a checkpoint: The spatiality of colonial encounters in occupied Palestine. Journal of Critical Race Inquiry, 1(1), 90-108.

Richardson, C. (2008). Canada's toughest neighbourhood: Surveillance, myth, and orientalism in Jane-Finch (master's thesis). Brock University, St. Catharines, ON.

Rigakos, G., Kwashie, F., \& Bosanac, S. (2004). The San Romanoway community revitalization project: Interim report. Retrieved from www.srra.ca/pdfs/2004\%20Report.pdf

Ross, G.M. (1992). The way must be tried: Memoirs of a university man. Toronto, ON: Stoddard Publishing.

Saunders, E. (2005). Appendix. Retrieved from http://www.yorku.ca/mediar/special/2005/LandAppendicesFINAL.pdf

Saunders, E. (2005). Review of sale of lands by York University to Tribute Homes in March 2002. Retrieved from http://www.yorku.ca/mediar/YorkReport.pdf

Smith, A. (2005). Conquest: Sexual violence and American Indian genocide. Boston, MA: South End Press.

Toronto Community Housing. (2012). About Us. Retrieved from https://www.torontohousing.ca/about

Toronto Police Services. (2012). TAVIS. Retrieved from http://www.torontopolice.on.ca/tavis/index.php 
Toronto Police Services. (2012). SIU Clears Officers. Retrieved from

http://www.torontopolice.on.ca/modules.php?op=modload\&name=News\&file=article \&sid $=5185$

United Nations. (1997). Human Development to Eradicate Poverty. New York, NY: Oxford University Press. Retrieved from United Nations Development Programme website: http://hdr.undp.org/sites/default/files/reports/258/hdr_1997 en_complete nostats.pdf

United Way of Greater Toronto. (2011). Poverty by postal code 2: Vertical povertyDeclining income, housing quality and community life in Toronto's inner suburban high-rise apartments. Retrieved from United Way website: http://www.unitedwaytyr.com/document.doc?id=89

Unterman, R., \& McPhail, B. (2008). Cultural heritage assessment report: Cultural heritage landscapes. York University Development Corporation. Toronto, ON: York University. Retrieved from https://www1.toronto.ca/city_of toronto/city_planning/community_planning/files/pdf/ yorku_draft_cultheritage_asses_rep_mar08.pdf

Wacquant, L. (2008). Urban outcasts: A comparative sociology of advanced marginality. Cambridge, United Kingdom: Polity Press.

Winsa, P. (2012, May 8). Inquest jury blames police for teen's death, but rules it an accident. Toronto Star. Retrieved from https://www.thestar.com

Winsa, P. (2012, January 30). Witnesses, coroner are wrong, officers tells inquest. Toronto Star. Retrieved from https://www.thestar.com

Wolfe, P. (2006). Settle colonialism and the elimination of the native. Journal of Genocide Research, 8(4), 387-409.

York University Development Corporation, (2012). Retrieved from http://www.yudc.ca

York University. (n.d.). The Jane-Finch community. Retrieved from http://www.yorku.ca/act/janefinchmap.html

York University. (2007, January 4). 'Reaching back' key to Westview Partnership's success. $y$ File. Retrieved from http://www.yorku.ca/yfile/archive/index.asp?Article=7661

York University. (2009, April 24). \$1-million grant backs research on marginalized urban youth. $y$ File. Retrieved from http://www.yorku.ca/yfile/archive/index.asp?Article $=12497$

York University. (2012, December 2). President's open forum on safety: Stronger together than apart. $y$ File. Retrieved from http://yfile.news.yorku.ca/2012/12/02/presidentsopen-forum-on-safety-stronger-together-than-apart 
York University. (2012). A Short History of York University. Retrieved from http://president.yorku.ca/about/

York University. (2012, November 19). Toronto 2015 breaks ground on new athletics stadium at York. yFile. Retrieved from http://yfile.news.yorku.ca/2012/11/19/toronto-2015breaks-ground-on-new-athletics-stadium-at-york-university

Zaami, M. (2012). Experiences of socio-spatial exclusion among Ghanaian immigrant youth in Toronto: A case study of the Jane and Finch neighbourhood (master's thesis). Western University, London, ON. 